\title{
The possibility of application of Sørensen and Renkonen indexes in the study of winter avifauna in small plots of the urban green areas
}

\author{
Tomasz Brauze*, Jacek Zieliński** \\ *Department of Vertebrate Zoology, Institute of Ecology and Environment Protection, N. Copernicus University, \\ Gagarina 9, 87-100 Torun, Poland \\ **Department of Zoology, University of Technology and Life Sciences, \\ Kordeckiego 20, 85-225 Bydgoszcz, Poland \\ corresponding author, e-mail: brauze@biol.uni.torun.pl
}

\begin{abstract}
Quantitative studies of winter avifauna (1999/2000) were conducted in three fragments of urban green areas in central Poland. Two observers independently controlled three plots six times, doing two subsequent counts (10 ha/1.5 hour) on the same day. All visits that were carried out in the same plot by the same observer during the same time of day were defined as a "survey". Differences between maximum and minimum values of similarity in species composition (Sørensen index - QS) and dominance structures (Renkonen index - Re) between two plots during all "surveys" ranged from 8.4 to $11.9 \%$ (QS) and from 11.8 to $22.4 \%$ (Re). Coefficients of variation (CV) for values of Sørensen and Renkonen indexes obtained for similarity of winter avifauna between two plots during all "surveys" ranged from 4.9 to $7.6 \%(\mathrm{QS})$ and from 8.9 to $14.1 \%$ (Re). Significant differences were found in one case between values of similarity in species composition (QS) obtained by two observers between two different plots (Mann-Whitney test, $U=0.0, n=8, P=0.02)$. The results show that there is no possibility to estimate clearly the similarity of dominance structure (Re) and, to a lesser degree, species composition (QS) of winter avifauna between two small fragments of the urban green areas.
\end{abstract}

Key words: Sørensen index, Renkonen index, species composition, winter avifauna, urban avifauna.

\section{Introduction}

Sørensen and Renkonen indexes give a possibility to compare bird communities by estimating the degree of similarity in species composition and dominance structure. In Polish literature the use of these indexes was applied to breeding bird communities as proposed by Tomiałojć (1970). The estimation of similarity between bird communities requires relatively stable species composition and a number of birds among compared time periods (Brauze $\&$ Zieliński 2006). Also the same study methods are required. Difficulties with meeting this kind of conditions for wintering bird communities in small urban green areas (Brauze \& Zieliński 2006) cause that Sørensen and Renkonen indexes, applied to this kind of research (e.g. Górska \&
Górski 1980; Luniak 1980; Biaduń 1994, 1996a, b; Clergeau et al. 2001), may provide information of little value.

The aim of this study was to recognize how possible changes in species composition, number of birds and problems with their detection, influence values of Sørensen and Renkonen indexes. The application of these indexes was tested for bird communities wintering on small urban green areas.

\section{Study area}

Studies on wintering birds were conducted in central Poland in three plots, parts of urban green areas in Bydgoszcz the plot BYD, Solec Kujawski - SOL and Torun -TOR. 
The plot BYD (14.5 ha; $\left.53^{\circ} 12^{\prime} \mathrm{N}, 17^{\circ} 98^{\prime} \mathrm{E}\right)$; about half of the plot was covered with one hundred years old riverine alder Alnus glutinosa forest and dense undergrowth, consisting mainly of elderberry Sambucus nigra shrubs. The rest of the area was covered by nearly one hundred years old pine Pinus sylvestris forest with sparse undergrowth. Grass areas with a few small buildings did not exceed 10\% of the study area.

The plot SOL (11.0 ha; $\left.53^{\circ} 08^{\prime} \mathrm{N} 18^{\circ} 21^{\prime} \mathrm{E}\right)$ was almost completely covered by low, nearly one hundred years old pine forest. Shrubs of low or medium density, mainly with black cherry Padus serotina, covered over half of the plot. A small part of the area had an open character.

The plot TOR (10.0 ha; $\left.53^{\circ} 00^{\prime} \mathrm{N}, 18^{\circ} 36^{\prime} \mathrm{E}\right)$; the northern part was covered with over one hundred years old pine forest with scarce undergrowth. A part of the area, adjacent to flooded riverine areas of the Vistula River, was covered by $70-100$ years old multi-species deciduous forest with dense undergrowth. Remains of the flooded riverine forest with old poplars Populus sp. covered a small part of the area. There were a few ponds in the park, with the total area not exceeding $1 \mathrm{ha}$, and a sport grass field.

\subsection{Material and methods}

The study was conducted from mid December 1999 to mid February 2000. Birds were counted independently by both authors (B and $\mathrm{Z}$ ), observers with similar field experience. Each observer (B and Z) controlled each plot six times, evenly on different dates, performing two subsequent counts on the same day, marked as the early one - E and the late one $-\mathrm{L}$. The first one was being started about 8.00 a.m. and the late count, performed right after the early one, was finished before noon. The counting rate was standardized to $10 \mathrm{ha} / 1.5$ hour, as in Biadun (1996a, b).

All six single counts of birds conducted in the same plot by one observer ( $B$ or $Z$ ) at the same time of the day were defined in this paper as a "survey". Thus four "surveys" marked with symbols BE, BL, ZE, ZL were obtained for each plot: observer B -6 early counts (BE) and 6 late counts (BL), observer $Z-6$ early counts (ZE) and 6 late counts (ZL).

The similarity of species composition was determined by the Sørensen index (QS), whereas the similarity of dominance structures by the Renkonen index (Re). Indexes were calculated as follows:

$$
\begin{array}{lc}
\mathrm{QS}=2 W^{*} 100 \% / A+B & \mathrm{Re}=\Sigma_{x} \\
A-\text { number of species in } & x-\begin{array}{l}
\text { minimum value of } \\
\text { dominance (\%) for }
\end{array} \\
\begin{array}{c}
\text { community } \\
\text { number of species in } B \\
\text { community }
\end{array} & \begin{array}{l}
\text { species in two comp } \\
\text { communities }
\end{array} \\
\begin{array}{l}
W \text { - species shared by } A \text { and } B \\
\text { communities }
\end{array} &
\end{array}
$$

Species composition of bird communities and dominance structures were compared among all surveys for each of the two plots (BYD/SOL, BYD/TOR, SOL/TOR). Therefore, 16 values of the similarity indexes, both QS and Re, were for each of the two compared plots (Tab. 1). Differences between the values of these indexes obtained by comparison of two data sets collected by different observers were defined as an INTER effect ( 8 values of QS and Re indexes; Tab. 1). The analogous differences in indexes' values obtained for the same observer were regarded as an INTRA effect: INTRA B and INTRA Z effect, for observer $B$ and $Z$ respectively (four values of QS and Re for each effect; Tab. 1). The Mann-Whitney test was used to compare similarity values for species composition (QS) and dominance structure $(\mathrm{Re})$ between distinguished effects. The significance level was at $\mathrm{p}<0.05$.

\section{Results}

During the quantitative studies of wintering avifauna in SOL, TOR and BYD plots, 22, 32 and 34 bird species were recorded respectively. Densities of avifauna obtained during four "surveys" in each plot were as follows: $82.3-138.4$ ind./10 ha - BYD, 46.7-57.6 ind./10 ha SOL and 145.8-204.2 ind./10 ha - TOR.

Differences between maximum and minimum values of similarity in species composition (QS) of avifauna of the two plots for all "surveys" ( $n=16$; Tab. 1$)$ ranged from 8.4 (BYD/SOL) to $11.9 \%$ (BYD/TOR); (Tab. 2). The analogous differences for the similarity of dominance structure (Re) ranged from 11.8 (SOL/TOR) to $22.4 \%$ (BYD/TOR); (Tab. 2). For INTER and INTRA effects $(n=8)$, differences between maximum and minimum values of QS and Re indexes were similar (Tab. 2). For INTRA B and INTRA Z effects $(n=4)$, differences between maximum and minimum values were in some cases considerably higher (e.g. values of Re index for BYD/TOR plots ranged from $2.2 \%$ for INTRA $Z$ effect to $18.2 \%$ for INTRA B effect). However, minimum and maximum values of the described differences were recorded for both INTRA B and INTRA $\mathrm{Z}$ effect (Tab. 1).

Coefficients of variation $(\mathrm{CV})$ for values of Sørensen and Renkonen indexes obtained for the similarity of winter avifauna between two plots during all "surveys" ranged from 4.9 to $7.6 \%(\mathrm{QS})$ and from 8.9 to $14.1 \%(\mathrm{Re})$. Analogous values of CV for INTER and INTRA effects were similar (Tab. 2). The biggest differences between CV values were recorded for INTRA B and INTRA $Z$ effects (e.g. for BYD/TOR plots for INTRA B and INTRA Z effects, the values were respectively: 1.5 and $8.4 \%$ for $Q S$, whereas 12.7 and $1.4 \%$ for Re; Tab. 2).

Significant differences were observed only for values of similarity in species composition for BYD/SOL plots 
Table 1. Similarity of bird species composition (Sörensen index - QS\%) and dominance structure (Renkonen index - Re\%) between "surveys" (BE, BL, ZE, ZL) in two plots BYD/TOR, SOL/BYD, SOL/TOR with distinguished effects: INTER (white, $n=8$ ), INTRA B (pale grey, $n=4$ ) and INTRA Z (dark grey, $n=4$ )

\begin{tabular}{cccccc}
\hline & \multirow{2}{*}{ QS } & \multicolumn{4}{c}{ BYD } \\
\cline { 3 - 6 } & & BE & BL & ZE & ZL \\
\hline \multirow{3}{*}{ BE } & 54.1 & 52.5 & 45.2 & 45.2 \\
${ } }$ & BL & 53.3 & 54.3 & 47.1 & 54.5 \\
& ZE & 57.1 & 53.0 & 50.6 & 55.7 \\
& ZL & 53.8 & 54.8 & 45.5 & 52.5
\end{tabular}

\begin{tabular}{ccccc}
\hline \multirow{2}{*}{ Re } & \multicolumn{4}{c}{ BYD } \\
\cline { 2 - 5 } & BE & BL & ZE & ZL \\
\hline BE & 70.2 & 88.1 & 68.2 & 68.8 \\
BL & 69.9 & 86.4 & 67.2 & 66.6 \\
ZE & 73.8 & 88.4 & 68.1 & 69.6 \\
ZL & 73.7 & 82.9 & 70.3 & 68.8
\end{tabular}

\begin{tabular}{cccccc}
\hline & \multirow{2}{*}{$\mathbf{Q S}$} & \multicolumn{4}{c}{ SOL } \\
\cline { 3 - 6 } & & $\mathbf{B E}$ & $\mathbf{B L}$ & $\mathbf{Z E}$ & $\mathbf{Z L}$ \\
\hline & $\mathbf{B E}$ & 48.1 & 46.7 & 50.0 & 50.0 \\
$\mathbf{0}$ & $\mathbf{B L}$ & 45.6 & 47.6 & 50.7 & 50.8 \\
& $\mathbf{Z E}$ & 44.1 & 46.2 & 49.3 & 49.2 \\
& $\mathbf{Z L}$ & 47.3 & 49.2 & 52.2 & 52.5
\end{tabular}

\begin{tabular}{ccccc}
\hline \multirow{2}{*}{$\mathbf{R e}$} & \multicolumn{4}{c}{ SOL } \\
\cline { 2 - 5 } & $\mathbf{B E}$ & BL & ZE & ZL \\
\hline BE & 42.5 & 40.5 & 50.1 & 41.2 \\
BL & 38.7 & 35.1 & 45.1 & 37.9 \\
ZE & 42.5 & 41.1 & 52.4 & 42.6 \\
ZL & 32.8 & 35.4 & 39.3 & 30.9
\end{tabular}

\begin{tabular}{|c|c|c|c|c|c|}
\hline & \multirow{2}{*}{ QS } & \multicolumn{4}{|c|}{ SOL } \\
\hline & & $\mathbf{B E}$ & BL & $\mathbf{Z E}$ & $\mathbf{Z L}$ \\
\hline \multirow{4}{*}{$\underset{\mathrm{O}}{\mathrm{O}}$} & $\mathbf{B E}$ & 52.0 & 46.4 & 53.1 & 50.0 \\
\hline & BL & 51.0 & 52.6 & 55.4 & 52.6 \\
\hline & $\mathbf{Z E}$ & 49.1 & 47.5 & 53.7 & 54.2 \\
\hline & $\mathbf{Z L}$ & 48.1 & 46.7 & 52.9 & 50.0 \\
\hline
\end{tabular}

\begin{tabular}{ccccc}
\hline \multirow{2}{*}{ Re } & \multicolumn{4}{c}{ SOL } \\
\cline { 2 - 5 } & BE & BL & ZE & ZL \\
\hline BE & 41.2 & 36.6 & 44.6 & 39.1 \\
BL & 38.8 & 34.5 & 44.5 & 37.1 \\
ZE & 39.4 & 35.1 & 43.2 & 38.1 \\
ZL & 40.8 & 36.5 & 46.3 & 39.2
\end{tabular}

Table 2. Ranges (max. - min.) and coefficients of variation (CV - \%) of values of Sörensen (QS - \%) and Renkonen (Re - \%) indexes obtained for similarity of winter avifauna between (/) study plots (BYD, TOR, SOL) for all "surveys" and individual effects (INTER, INTRA, INTRA B, INTRA Z)

\begin{tabular}{|c|c|c|c|c|c|c|c|}
\hline & & \multicolumn{2}{|c|}{ BYD/TOR } & \multicolumn{2}{|c|}{ BYD/SOL } & \multicolumn{2}{|c|}{ SOL/TOR } \\
\hline & & QS & $\operatorname{Re}$ & QS & $\operatorname{Re}$ & QS & $\operatorname{Re}$ \\
\hline \multirow{2}{*}{ All "surveys" } & $\max .-\min$. & 11.9 & 22.4 & 8.4 & 21.5 & 9.0 & 11.8 \\
\hline & $\mathrm{CV}$ & 7.6 & 10.7 & 4.9 & 14.1 & 5.5 & 8.9 \\
\hline \multirow{2}{*}{ INTER } & $\max .-\min$. & 11.9 & 22.4 & 6.7 & 17.3 & 8.7 & 9.5 \\
\hline & $\mathrm{CV}$ & 9.2 & 11.0 & 5.0 & 13.5 & 6.1 & 8.9 \\
\hline \multirow{2}{*}{ INTRA } & $\max .-\min$. & 10.2 & 20.0 & 6.9 & 21.5 & 7.8 & 11.8 \\
\hline & $\mathrm{CV}$ & 6.0 & 11.2 & 5.0 & 15.6 & 4.9 & 9.5 \\
\hline \multirow{2}{*}{ INTRA B } & $\max .-\min$. & 1.8 & 18.2 & 2.5 & 7.4 & 6.2 & 6.7 \\
\hline & $\mathrm{CV}$ & 1.5 & 12.7 & 2.4 & 8.0 & 5.6 & 7.6 \\
\hline \multirow{2}{*}{ INTRA Z } & $\max .-\min$. & 10.2 & 2.2 & 3.3 & 21.5 & 4.2 & 8.2 \\
\hline & CV & 8.4 & 1.4 & 3.5 & 21.5 & 3.6 & 9.1 \\
\hline
\end{tabular}


between INTRA B/INTRA $Z$ effects (the Mann-Whitney test: $U=0.0, n=8, P=0.02)$. In this case, all values of the Sørensen index obtained by $\mathrm{Z}$ observer were higher than values obtained by B observer (Tab. 1). Such differences were not recorded for the remaining values, for the similarity of species composition and dominance structure indexes, obtained for plots: BYD/SOL, BYD/TOR, SOL/ BYD, and between effects: INTER/INTRA, INTER/INTRA B, INTER/INTRA Z, INTRA B/INTRA Z (the MannWhitney test, for $P<0.05$ ).

\section{Discussion and conclusions}

High values of coefficients of variation and large differences in maximum and minimum values of similarity in the dominance structure (Re), and to a lesser degree in species composition (QS), obtained for wintering bird communities in two plots during the same season were caused mainly by two factors. Firstly, there are considerable difficulties with the assessment of the real number of birds in the plot (Nilsson 1974; Tomiałojć 1974; Brewer 1978; Donald et al. 1997). Secondly, species composition and the number of birds in the small plot change during the whole winter (Källander et al. 1977; Jokimäki \& Suhonen 1998; Brauze \& Zieliński 2003, 2004, 2006). Under such conditions, even during one winter day the same observer can obtain a different, statistically significant, number of birds (Brauze \& Zieliński 2003). Consequently, the comparison of winter avifauna between two different areas may reflect only temporary stages of the dynamic system of the number of birds and species richness. Additionally, difficulties with the assessment of the real number of birds are superimposed on this dynamic system.

As a consequence of large differences between the obtained values of the Re index is the fact that "proper" estimation of the dominance and structure similarity becomes problematic. Thus, according to the three-step interpretation of the Re index $(0-50,50-70,70-100 \%)$ proposed by Tomiałojć (1970), in some cases, it would be justified to apply two different similarity categories for the dominance structure between TOR/BYD and BYD/SOL plots (Tab. 1).

Significant differences between INTRA B/INTRA Z effects in the similarity of species composition were recorded only once (the Mann-Whitney test). This implies that despite of the wide range of values obtained for QS and Re indexes, the observers in the present study had no clear tendency to over- or underestimate the similarity in winter avifauna. Differences in the obtained similarity indexes would probably be much higher if this study were conducted by observers with considerably different field experience, such as in Källander et al. (1977), Fannes and Bystrak (1981), Tomiałojć (1992), Rosenstock et al. (2002).
The obtained results point out the lack of possibility for unambiguous estimation of the dominance structure similarity ( $\mathrm{Re}$ ), and to a lesser degree, also bird species composition (QS), for winter avifauna in two small plots in the urban green areas.

\section{References}

Biaduń W., 1994, Winter avifauna of urban parks and cemeteries in Lublin (SE Poland), Acta Ornithol. 29: $15-27$.

Biaduń W., 1996a, Ptaki lęgowe i zimujące osiedli mieszkaniowych w Lublinie [Breeding and wintering avifauna of the housing estates in Lublin], Notatki Ornitol. 37: $83-95$.

Biaduń W., 1996b, Ptaki ogródków działkowych w Lublinie [Avifauna of the allotment gardens in Lublin], Notatki Ornitol. 37: 247-258.

Brauze T. \& Zieliński J., 2003, Intrapersonalne i interpersonalne różnice pomiędzy wynikami ilościowych badań zimowych nad awifauną wybranych gatunków krukowatych Corvidae w zieleni miejskiej [Intraand inter-personal differences in results of quantitative winter studies on selected species of corvids Corvidae in urban green areas], [in:] A. Przystalski \& B. Wilczyńska (eds.), Zoologia na progu XXI wieku [Zoology at the beginning of the $21^{\text {st }}$ century], PZITS, Toruń: 96-97.

Brauze T. \& Zieliński J., 2004, Bogactwo gatunkowe i wykrywalność gatunków awifauny zimowej na niewielkich powierzchniach zieleni miejskiej [Species richness and detectability of winter avifauna species on small urban green areas], [in:] P. Indykiewicz \& T. Barczak (eds.), Fauna miast Europy Środkowej XXI wieku [Urban fauna of Central Europe in the $21^{\text {st }}$ century], LOGO, Bydgoszcz: 531-536.

Brauze T. \& Zieliński J., 2006, Are winter species composition and abundance censuses of birds in small urban green areas comparable?, Acta Ornithol. 41: 93-101.

Brewer R., 1978, A comparison of three methods of estimating winter bird populations, J. Field Ornithol. 49: $252-261$.

Clergeau P., Jokimäki J. \& Savard J.-P. L., 2001, Are urban bird communities influenced by the bird diversity of adjacent landscapes?, J. Appl. Ecol. 38: 1122-1134.

Donald P. F., Haycock D. \& Fuller R. J., 1997, Winter bird communities in forest plantations in western England and their response to vegetation, growth stage and grazing, Bird Study 44: 206-219.

Fannes C. A. \& Bystrak D., 1981, The role of observer bias in the North American breeding bird survey, [in:] C. J. Ralph \& J. M. Scott (eds.), Estimating the numbers of terrestrial birds, Stud. Avian Biol. 6: 353-359. 
Górska E. \& Górski W., 1980, Zimowanie ptaków w Poznaniu [Birds wintering in Poznań], Acta Ornithol. 17: $271-295$.

Jokimäki J. \& Suhonen J., 1998, Distribution and habitat selection of wintering birds in urban environments, Landsc. Urban Plann. 39: 253-263.

Källander H., Nilsson S. G. \& Svensson S., 1977, The Swedish Winter Bird Census Programme, Pol. Ecol. Stud. 3: 77-88.

Luniak M., 1980, Birds of allotment gardens in Warsaw, Acta Ornithol. 17: 297-319.

Nilsson S. G., 1974, Methods of estimating bird population densities during the winter, Ornis Scand. 5: 37-46.

Rosenstock S. S., Anderson D. R., Giesen K. M., Leukering T. \& Carter M. F., 2002, Landbird counting techniques: current practices and an alternative, Auk 119: 46-53.
Tomiałojć L., 1970, Badania ilościowe nad synantropijną awifauną Legnicy i okolic [Quantitative studies on the synanthropic avifauna of Legnica and its environs], Acta Ornithol. 12: 293-392.

Tomiałojć L., 1974, Charakterystyka ilościowa lęgowej i zimowej awifauny lasów okolic Legnicy (Dolny Śląsk) [The quantitative analysis of the breeding and winter avifauna of the forests in the vicinity of Legnica (Lower Silesia)], Acta Ornithol. 14: 59-97.

Tomiałojć L., 1992, Czy wyniki metody kartograficznej są porównywalne pomiędzy oddzielnie pracującymi, niedoświadczonymi obserwatorami? [Are the mapping technique results comparable between inexperienced observers working independently?], Notatki Ornitol. 33: $131-139$. 